\title{
SIMULATION OF AIR CHARACTERISTICS FOR PV HYBRID DRYING SYSTEM AND DRYING KINETICS OF STRAWBERRY FRUITS
}

\author{
B. M. A. Amer*
}

\begin{abstract}
Strawberry is an important fruit and could be dried to use throughout the year. A Photovoltaic (PV) hybrid solar dryer with water storage heat unit was conducted to can operate the drying for strawberry fruits continually at day and night using the stored heat. It is used to avoid the problems of sun drying as dust, pests, poor quality for dried products and long time for process. A COMSOL Multiphysics computer program was used the dimensions of the solar collector and the drying chamber, the measured inlet and outlet of the air characteristics to simulate the distribution of the air temperature, air velocity and pressure inside the solar collector and the drying chamber. It found that the air characteristics inside both of these parts were almost equivalent and it was in small scale difference. However, a theoretical approach based on mass transfer kinetics is used to model the change in moisture content of the food product. Moisture content of strawberry fruits was fitted to various thin-layer models. Based on the values of these statistical parameters obtained, the two-term model represented drying characteristics better than other models. The moisture diffusivity during solar drying process for strawberry fruits was ranged from $7.2 \times 10^{-9}$ to $9.5 \times 10^{-9} \mathrm{~m}^{2} / \mathrm{s}$. This paper presents an analytical approach for the solar drying of strawberry and the results are important for future validation studies using other products.
\end{abstract}

Keywords: COMSOL simulation, Solar drying, storage, PV, Strawberry.

\section{INTRODUCTION}

trawberry (Fragaria $\mathbf{x}$ ananassa) is a sweet fruit which used often as a fresh in the Arab countries and in Saudi Arabia, however it could use as dried products or rehydrated to use in/as sweets or cakes throughout the year. The world production of strawberries in 2017 was 9.22 million tons, (FAOSTAT, 2018).

\footnotetext{
*Agricultural Engineering Department, Faculty of Agriculture, Cairo University, Egypt.
} 
Drying of agricultural products in Saudi Arabia is normally carried out by artificial methods with high costs or by traditional sun drying method with not high quality for products and long time for the drying process. Preservation of agricultural products by drying prevents the growth of pests and insects to reduce quality of these products. The main cause of pest and insect attack is high moisture content in agricultural products in air. Otherwise, vegetables and fruits are deteriorated rapidly and loses its viability. As a result, a significant loss of the harvested seeds in both quality and quantity occurs. Sometimes, continuous rain occurs for some days, spoils whole quantity of seeds due to lack of drying facilities.

There is a problem for using solar drying in large scale that could not operate at night and instability of solar radiation which is affecting on the quality of dried products. Storing energy one of the best solutions for this problem, (Arinze et al. 1999 and Shalaby, and Bek 2014). In addition, it will reduce the cost of fabrication and production.

Besides some researchers were found that both heat storage and supplementary heat resource are important to complete the solar drying requirements of air temperature, (Vlachos et al. 2002 and Amer et al. 2010), was performed a new design of hybrid solar dryer for banana. This dryer can be stored the solar energy in the water and use it beside the electricity to raise the drying air temperature at night. Few researches were done for solar drying of strawberry as El-Beltagy et al. (2005).

Therefore, a movable solar dryer has been developed at Agricultural Systems Engineering at College of Agricultural \& Food Sciences, King Faisal University. This dryer is found suitable for drying of fruits and vegetables. A storage water reservoir could be connected to this dryer to operate the drying process at night as well as the day. To avoid usage of electricity supply and saving its cost, a photovoltaic module and storage batteries will be incorporated to operate electric dc blower and electric dc water pump. However, the dryer may be operated during sunny days independent of supply and in adverse weather (rainy, cloudy and foggy) using the storage energy. The dryer will then be demonstrated and disseminated among the growers and traders.

Thus, the farmers as well as the producers can produce quality dried vegetables and fruits to attain food security. 
Therefore, the objectives of present study are:

1. to investigate the distribution of the air temperature, air velocity and pressure inside the solar collector and the drying chamber using $A$ COMSOL Multiphysics computer program.

2. to develop moisture transfer models for thin-layer drying of strawberry fruits on scale solar drying system. Strawberry is a good consistency that facilitates easy application and investigation of drying characteristics in single layer to evaluate the suitability of some thin layer drying models.

\section{MATERIALS AND METHODS}

\section{PV hybrid solar drying system:}

This solar dryer consists of movable solar collector with heat exchanger, connected to heat storage unit, movable drying chamber, and PV module could be showed in Fig. 1., and the dimensions of the parts for PV hybrid Solar dying system, Table 1 . The system made from readily available local materials as showed.

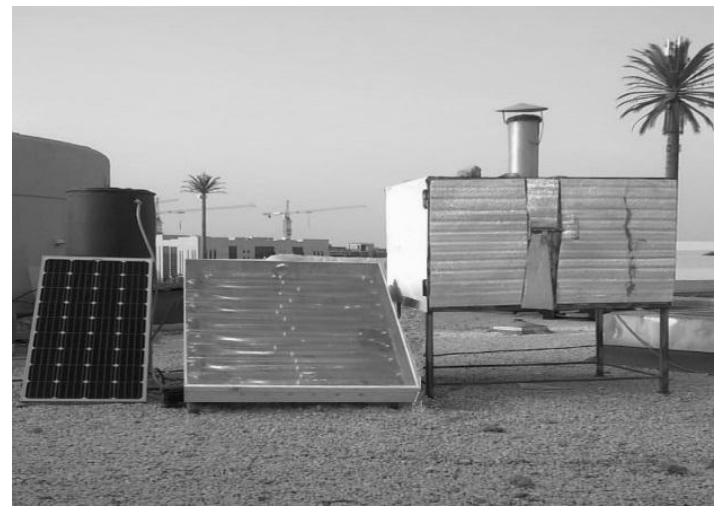

Fig. 1. The PV solar drying system.

All the solar drying setup and the experiments was done at College of Agricultural \& Food Sciences, King Faisal University (KFU), Al Hufuf, Al-Hasa, Saudi Arabia (25 $18^{\prime}$ N Latitude, 49 $29^{\prime}$ E Longitude), in March 2018. The drying experiments were driven at day-time from 8 a.m to 6 p.m (around 10 hours), and continues at night time till the sun-shine at next day.

Table 1. the dimensions of the parts for PV hybrid Solar dying system

\begin{tabular}{|l|l|l|}
\hline Item & Dimensions & Remarks \\
\hline Solar collector & $180 \times 120 \times 20 \mathrm{~cm}$ height & angle $30^{\circ} \mathrm{C}$ slope (south direction) \\
\hline Heat Storage tank & $120 \mathrm{~cm} \mathrm{ht.} \mathrm{\times} \mathrm{90cm} \mathrm{diameter}$ & $(120$ litters $)$ \\
\hline Drying chamber & $150 \times 100 \times 180 \mathrm{~cm}$ height & $5 \mathrm{~mm}$ fiber-glass insulation \\
\hline PV module & $148 \times 68 \times 35 \mathrm{~cm}$ thickness & $(150$ watts $)$ \\
\hline
\end{tabular}




\section{The air characteristics:}

\subsection{Air temperature:}

AT4508 Multi-channel temperature meter (Data logger + 32 K-type Thermocouples) is used for measuring the air temperature at 32 points.

\subsection{Air velocity:}

Anemometer (accuracy 0.1 m per second) is used for measuring air velocity.

\subsection{Solar Radiation:}

Pyranometer (Hukseflux-Thermal sensors type LP02) is used for measuring hemispherical solar radiation in $\mathrm{Wm}^{2}$.

\section{Strawberry characteristics:}

\subsection{Preparation of strawberry:}

Driscoll's strawberry variety imported from USA were purchased from local supermarket for drying studies. This was done to reduce possible quality degradation of the strawberry before the start of experiments. strawberry was used as a model food in these studies because of its good film-forming ability. The strawberry fruits were spent at room temperature for 6 to $8 \mathrm{~h}$ before using in the experiments.

\subsection{The moisture content for fresh and dried product:}

The initial moisture content of fresh and dried material was determined by Moisture analyzer.

The moisture content (dry basis) was calculated according to the equation:

$$
\mathrm{M}_{\mathrm{d}}=\left[\frac{\mathrm{w}_{\mathrm{w}}-\mathrm{w}_{\mathrm{d}}}{\mathrm{w}_{\mathrm{d}}}\right]
$$

Where

$\mathrm{M}_{\mathrm{d}}$ moisture content of material at time $\mathrm{t}_{\mathrm{i}}$, (dry basis), \%

$\mathrm{W}_{\mathrm{w}}$ mass of wet material, $(\mathrm{g}) \quad \mathrm{W}_{\mathrm{d}}$ mass of dry matter, $(\mathrm{g})$

For the determination of the moisture content, wet basis, of the material at any time " $\mathrm{t}_{\mathrm{i}}$ " during drying process, the following equation could be used:

$$
\operatorname{Md}_{i}=\frac{W_{i}-\mathrm{W}_{d}}{W_{d}} \times 100
$$

$\mathrm{Md}_{\mathrm{i}}$ moisture content, dry basis of the material at any time.

$\mathrm{W}_{\mathrm{d}} \quad$ mass of the dried sample, $(\mathrm{kg})$

$\mathrm{W}_{\mathrm{i}} \quad$ mass of the material at time $\mathrm{t}_{\mathrm{i}},(\mathrm{kg})$.

The determination of the material mass was done by weighing the drying tray with its load of material at any time during the drying process. 


\subsection{Color measurement for strawberry fruits:}

Minolta colorimeter (CR400 model) was used to estimate the color parameters. Values of chroma are 3 resolutions for fruit along perpendicular axes, $\mathrm{L}^{*}, \mathrm{a}^{*}$, and $\mathrm{b}^{*}$ which could record, (Yam and Papadakis, 2004).

\section{Heat and mass balance for solar drying system:}

COMSOL Multiphysics 5.2 is a computer program was used to simulate the distribution of the air temperature and air velocity inside the solar collector and the drying chamber during the solar drying of strawberry.

The mass and energy equations in the steady state, were used for energy analysis of product drying process in hourly basis in order to optimize the drying conditions (Hepbasli, 2008):

The mass balance equation between inlet $\left(\mathrm{m}_{\text {in }}\right)$ and outlet $\left(\mathrm{m}_{\text {out }}\right)$ is:

$$
\sum m_{\text {in }}=\sum m_{\text {out }}
$$

The net energy balance equation between inlet $\left(Q_{\text {in }}\right)$ and outlet $\left(Q_{\text {out }}\right)$ is:

$$
\sum Q_{\text {in }}=\sum Q_{\text {out }}
$$

\subsection{Mass of water to be removed from total mass of the fresh product:}

The exchange of moisture between the product and the air inside the dryer satisfies a mass balance relationship where moisture lost by the product is picked up by air.

The total mass of water to be removed from the total mass of the fresh fruit (Sodha et al., 1987), is:

$$
\mathrm{m}_{\mathrm{w}}=\mathrm{m}_{\mathrm{p}} \times\left[\frac{\mathrm{M}_{\mathrm{i}}-\mathrm{M}_{\mathrm{f}}}{100-\mathrm{M}_{\mathrm{f}}}\right]
$$

Where

$\mathrm{m}_{\mathrm{w}}$ removed mass of water from the total mass of fresh strawberry, $\left(\mathrm{kg}_{\mathrm{w}}\right)$

$\mathrm{m}_{\mathrm{p}}$ mass of fresh strawberry at the beginning of drying process, $\left(\mathrm{kg}_{\mathrm{p}}\right)$

$\mathrm{M}_{\mathrm{i}}$ moisture content, wet basis, of fresh product.

$\mathrm{M}_{\mathrm{f}}$ final moisture content, wet basis, of product.

\subsection{The rate of heat transfer from the surface of product to the air:}

It could be determined from the following equation is given as $Q$ :

$$
Q=U A(\Delta T)
$$

where

$U$ heat transfer coefficient from air to the surface of wet material, $\left(\mathrm{W} / \mathrm{m}^{2} \mathrm{~K}\right)$; 
$\Delta \mathrm{T}$ temperature difference between air and the product surface, $(\mathrm{K})$;

A area through which the transfer is taking place, $\left(\mathrm{m}^{2}\right)$.

\section{Determination of the effective moisture diffusivity for strawberry:}

From Fick's second law of diffusion (Eq.7) was used to fit the experimental data for the determination of moisture diffusivity:

$$
\frac{\partial M}{\partial t}=D_{\text {eff }} \nabla^{2} M
$$

The solution of the previous diffusion equation for sphere/round geometry was solved by assuming uniform initial moisture distribution, negligible external resistance, constant diffusivity, and negligible shrinkage (Crank, 1975) was used by El-Beltagy et al. (2005) and (Lee and Hsieh, 2008):

$$
M R=\frac{6}{\pi^{2}} \sum_{n=1}^{\infty} \frac{1}{n^{2}} \exp \left(\frac{-n^{2} \pi^{2} t D_{e f f}}{L^{2}}\right)
$$

where $\mathrm{MR}$ is a dimensionless moisture ratio, $D_{\text {eff }}$ effective moisture diffusivity of product $\left(\mathrm{m}^{2} \cdot \mathrm{s}^{-1}\right), t$ time (s), and $L$ half-thickness of sample (m). This model assumes zero volume change, negligible external mass transfer resistance and an isothermal process.

The diffusion equation developed for particles with sphere/round geometry is applicable assuming that the diffusivity is constant and is in the form of the following equation:

$$
\begin{aligned}
& M R=\frac{M-M_{e}}{M_{o}-M_{e}}= \\
& \frac{6}{\pi^{2}}\left[\begin{array}{c}
\exp \left(\frac{-\pi^{2} t D_{\text {eff }}}{L^{2}}\right)+\frac{1}{4} \exp \left(\frac{-4 \pi^{2} t D_{\text {eff }}}{L^{2}}\right) \\
+\frac{1}{9} \exp \left(\frac{-9 \pi^{2} t D_{\text {eff }}}{L^{2}}\right)+\frac{1}{25} \exp \left(\frac{-25 \pi^{2} t D_{\text {eff }}}{L^{2}}\right)+. .
\end{array}\right]
\end{aligned}
$$

For long drying times where the Fick's number is greater than 0.1 and $M \mathrm{R}$ $<0.6$, a limiting form of equation (7), expressed in a logarithmic form, is obtained (Rahman et al., 1998; Rahman and Lamb, 1991; Madamba, 2003). After linearizing, a simplified form is obtained:

$$
\ln M R=\ln \left(\frac{6}{\pi^{2}}\right)-\left(\frac{\pi^{2} D_{e f f} t}{L^{2}}\right)
$$

For nonlinear experimental drying curves, the effective moisture diffusivity at various moisture ratios is determined using the ratio of slopes method. The effective diffusivities at different moisture ratios and drying time were calculated based on the ratio of the experimental drying curves to the slope of the theoretical curves at the same moisture contents. 


$$
D_{\text {eff }}=\left(\frac{d M R}{d t}\right)_{\exp } /\left(\frac{d M R}{d t}\right)_{t h} \times L^{2}
$$

where $(d M R / d t)_{\exp }$ represents the slope of experimental drying curves and $(d M R / d F)_{\text {th }}$ is the slopes of theoretical curves calculated by differentiating Eq. (9) with respect to $F$ (Fourier number, $F=D_{\text {eff }} t / L^{2}$ ), and taking the first term of series solution.

$$
\left(\frac{d M R}{d F}\right)_{t h}=-6 \exp \left(-\frac{\pi^{2} D_{e f f} t}{L^{2}}\right)
$$

The effective moisture diffusivity, $D_{\text {eff, }}$, in equations (11) and (12), was calculated simultaneously using Microsoft Excel spreadsheet program.

The average effective moisture diffusivity for each drying condition was calculated from a summation of effective diffusivity at different moisture ratio and dividing by the total number of data points (n).

$$
D_{\text {eff }, \text { ave }}=\frac{\sum_{1}^{n} D_{\text {eff }}(M R)}{n}
$$

\section{Data analysis and model development}

Thin-layer models have been applied to describe drying process of various products and drying methods. Several thin layer drying models are available in the literature for explaining drying characteristics of fruits and vegetables. Among these are the ones used by Afzal and Abe (2000) for potato slices; Karathanos and Belessiotis (1999) for fig and Togrul and Pehlivan (2003) for apricot.

The drying data, reported as moisture ratio MR versus drying time, were fitted to 10 thin layer drying models. These 10 commonly used thin layer equations were used to fit the experimental data by the direct least square method using SPSS 24 software.

No relevant literature was available in which drying strawberry is described in a manner similar to solar drying process. Therefore, all the models in Table 2 were evaluated. There is, in fact, no universal model that can fit all the data. The suitability of the model is strongly dependent on the characteristics of product and drying technique.

The statistical analysis items which coefficient of determination $\left(\mathrm{R}^{2}\right)$, reduced chi-square or reduced mean square of the deviation $\left(\chi^{2}\right)$, root mean square error (RMSE) and modeling efficiency (EF). These items were used to evaluate the suitability of different models to fit experimental data: 


$$
\begin{aligned}
& R^{2}=1-\frac{\sum_{1}^{N}\left(M R_{\text {exp } i}-M R_{p r e i}\right)^{2}}{\frac{1}{N} \sum_{1}^{N}\left(M R_{\text {exp } i}\right)^{2}} \\
& \chi^{2}=\frac{\sum_{i=1}^{N}\left(M R_{\exp i}-M R_{p r e, i}\right)^{2}}{N-n} \\
& R M S E=\left(\frac{1}{N} \sum_{i=1}^{N}\left(M R_{p r e, i}-M R_{\exp i}\right)^{2}\right)^{0.5} \\
& E F=\frac{\sum_{i=1}^{N}\left(M R_{\exp i}-M R_{\exp p v e}\right)^{2}-\sum_{i=1}^{N}\left(M R_{p r e, i}-M R_{\exp i}\right)^{2}}{\sum_{i=1}^{N}\left(M R_{\exp i}-M R_{\text {exp } p v e}\right)^{2}}
\end{aligned}
$$

where $\mathrm{R}$;exp;i and MR;pre;i are experimental and predicted dimensionless moisture ratios, respectively; $\mathrm{N}$ is number of observations; and $\mathrm{z}$ is number of constants. The best model describing the drying characteristics of samples was chosen as the one with the highest coefficient of determination, the least reduced chi-square, root mean square error, and mean relative percentage error.

Table 2. Mathematical models given by various authors for the drying curve

\begin{tabular}{|l|l|l|}
\hline Model Name & Model & References \\
\hline Lewis & $M R=\exp (-k t)$ & Sarsavadia et al. $(1999)$ \\
\hline Page & $M R=\exp \left(-k t^{n}\right)$ & Chhninman $(1984)$. \\
\hline Modified Page & $M R=\exp \left(-(k t)^{n}\right)$ & White et al. $(1981)$. \\
\hline $\begin{array}{l}\text { Henderson and } \\
\text { Pabis }\end{array}$ & $M R=a \exp (-k t)$ & $\begin{array}{l}\text { Chhninman }(1984) \text { \& Rahman } \\
\text { et al. }(1998)\end{array}$ \\
\hline Logarithmic & $M R=a \exp (-k t)+c$ & Vengaiah and Pandey (2007) \\
\hline Two-term & $M R=a \exp \left(-k_{1} t\right)+b \exp \left(-k_{2} t\right)$ & $\begin{array}{l}\text { Henderson (1974) \& Rahman } \\
\text { et al. }(1998)\end{array}$ \\
\hline $\begin{array}{l}\text { Two-term } \\
\text { exponential }\end{array}$ & $M R=a \exp (-k t)+(1-a) \exp (-k a t)$ & Sharaf-Eldeen et al. (1980) \\
\hline Midilli et al. & $M R=a \exp \left(-k t^{n}\right)+b t$ & Midilli et al. $(2002)$ \\
\hline $\begin{array}{l}\text { Diffusion } \\
\text { approximation }\end{array}$ & $M R=a \exp (-k t)+(1-a) \exp (-k b t)$ & Kassem (1998). \\
\hline Verma et al. & $M R=a \exp (-k t)+(1-a) \exp (-g t)$ & Verma et al. (1985) \\
\hline
\end{tabular}

\section{RESULTS AND DISCUSSION}

\section{The air characteristics on solar Drying of strawberry fruits:}

The summary for temperature values which were measured during solar drying for strawberry fruits in this study could be obtained in Table 3 . These measured data were used to simulate the distribution of air characteristics in the solar collector and drying chamber. 
Table 3: Summary for mean of the measured air characteristics inside during solar collector and drying chamber for Strawberry

\begin{tabular}{|l|c|}
\hline \multicolumn{1}{|c|}{ Item } & Value \\
\hline Solar radiation over the surface of solar collector & $1790-1850 \mathrm{~W} / \mathrm{m}^{2}$ \\
\hline Temperature of water after heating in water tank & $56-61^{\circ} \mathrm{C}$ \\
\hline Temperature of absorber & $93-94^{\circ} \mathrm{C}$ \\
\hline Temperature of glass for solar collector & $61-62^{\circ} \mathrm{C}$ \\
\hline Temperature of ambient air & $23-25^{\circ} \mathrm{C}$ \\
\hline Temperature of air at the exit from dryer & $43-46^{\circ} \mathrm{C}$ \\
\hline Air velocity at the inlet and outlet of solar collector & $0.02 \mathrm{~m} / \mathrm{s}$ \\
\hline Air velocity inside the pipe and at the inlet of chamber & $0.5 \mathrm{~m} / \mathrm{s}$ \\
\hline Air velocity at the inside drying chamber & $3 \mathrm{~m} / \mathrm{s}$ \\
\hline
\end{tabular}

2. Simulation for the Distribution of drying air characteristics inside the solar collector and drying chamber:

The following figures showed that the simulated distribution of the air temperature, air velocity and pressure inside the solar collector and the drying chamber using the COMSOL Multiphysics 5.2 computer program by the measured data of the air characteristics, as should in Table 2. The results showed that the air characteristics were stable and equal in each of both parts and the difference was in small scale, (Figures 2 to 7).

Fig. 2 showed that the mean air tempaerature inside the solar collector ranged from $298 \mathrm{~K}$ at the inlet point to $337 \mathrm{~K}$ at the outlet point acoording to the mean of solar radiation located over the glass cover of solar collector.

Fig. 3 showed that the mean air tempaerature inside the solar collector ranged from nearly zero beside the walls and the sides of it ranged to $0.02 \mathrm{~m} / \mathrm{s}$ at the rest of it. Fig. 4 showed that the mean air presure inside the solar collector ranged from $4 \times 10^{-4} \mathrm{~Pa}$ at the inlet point to $1 \times 10^{-4} \mathrm{~Pa}$ at the rest and the outlet point. Fig. 5 showed that the mean air tempaerature inside the drying chamber ranged from 326 at the inlet point at the bottom to $312 \mathrm{~K}$ at the outlet point at the upper side acoording to unform distrbution of air inside the drying chamber.

Fig. 6 showed that the mean air velosity inside the drying chamber ranged from $0.2 \mathrm{~m} / \mathrm{s}$ at the inlet point at the bottom to $2.5 \mathrm{~m} / \mathrm{s}$ at the outlet point at the upper side acoording to uniform distrbution of air inside the drying chamber. 


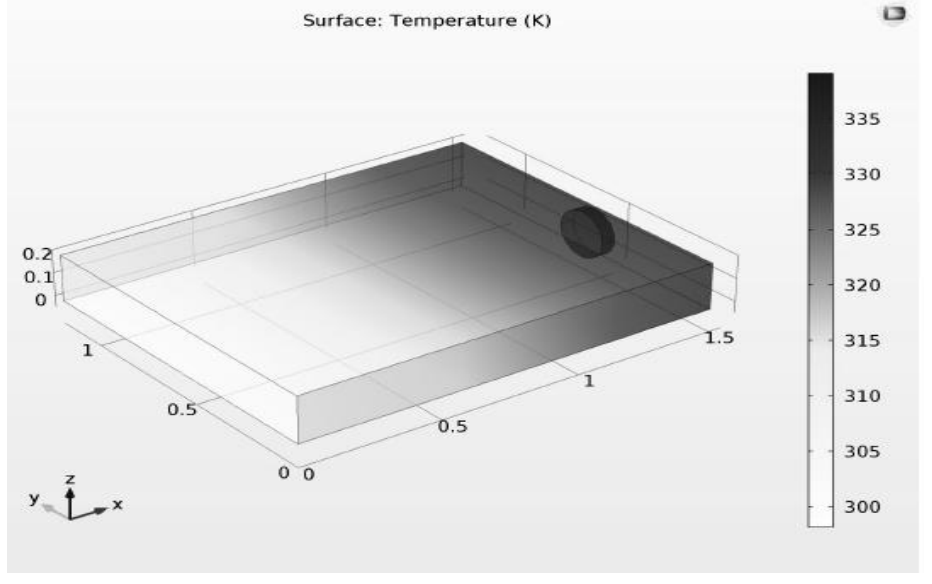

Fig. 2. Air temperature (K) distribution inside the solar collector

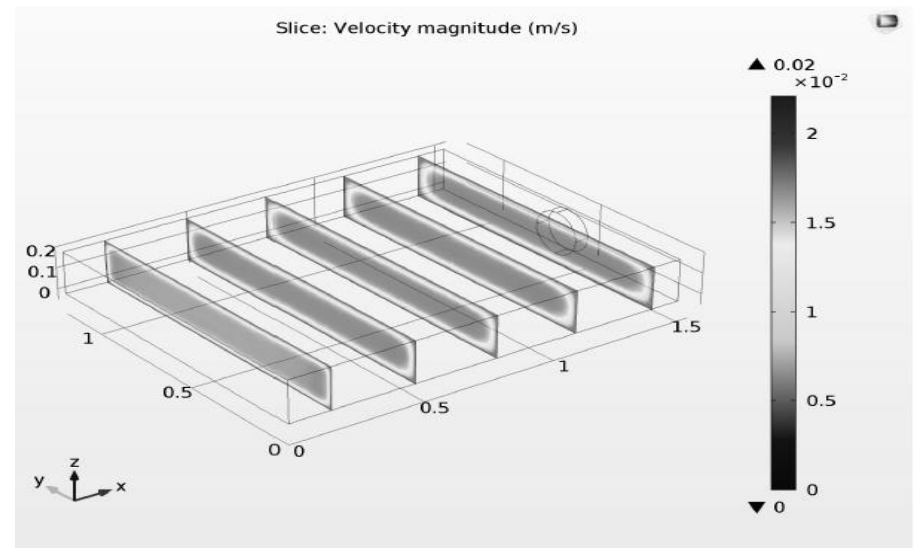

Fig. 3. Air velocity $(\mathrm{m} / \mathrm{s})$ distribution inside the solar collector

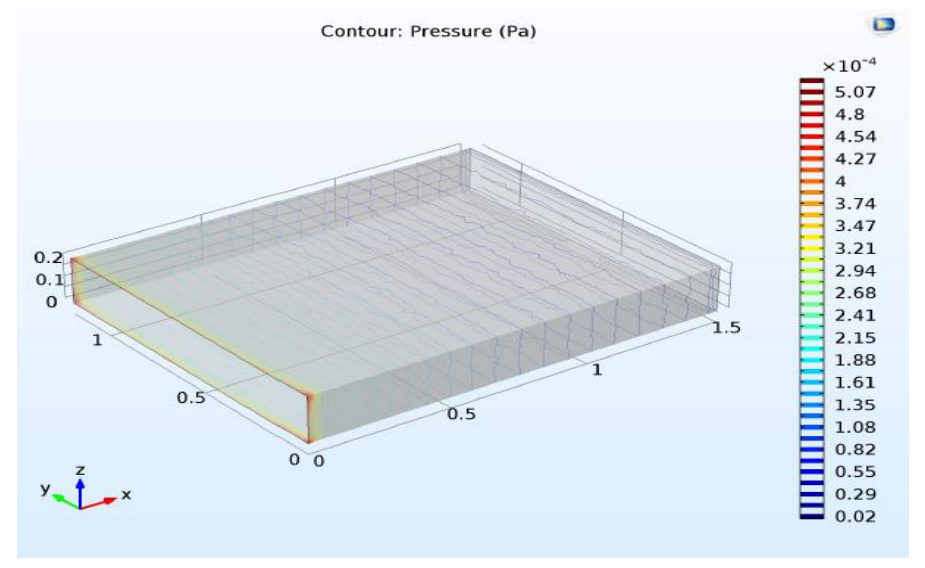

Fig. 4. Air pressure (Pa) distribution inside the solar collector 


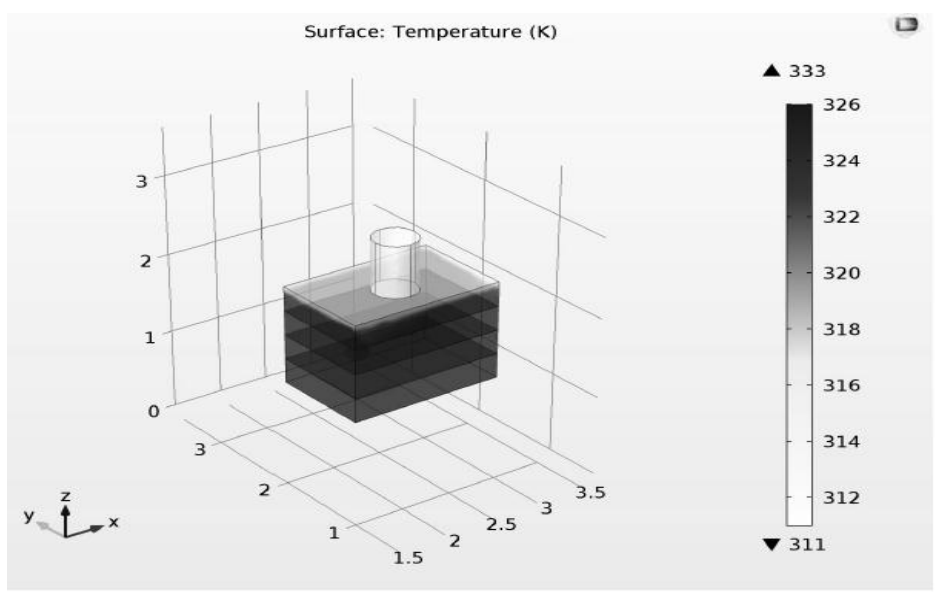

Fig. 5. Air temperature (K) distribution inside the drying chamber

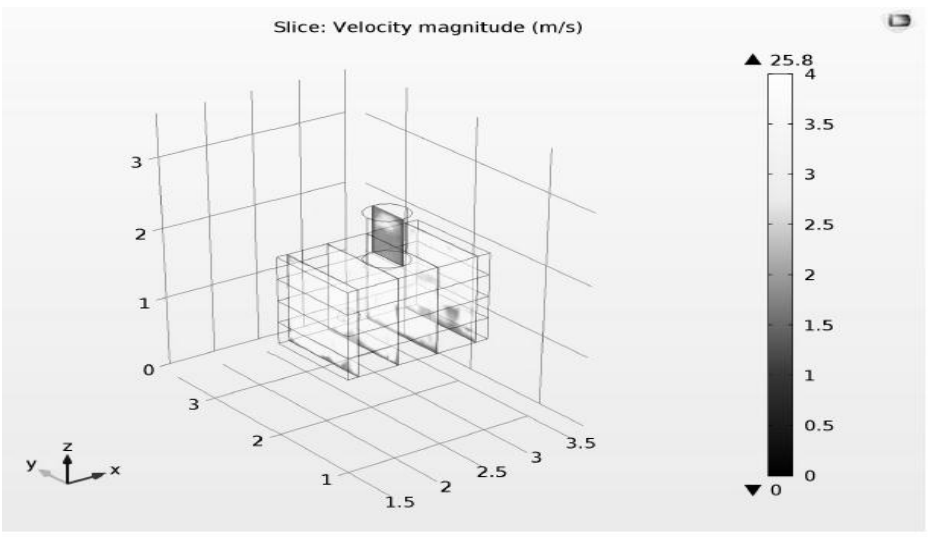

Fig. 6. Air velocity $(\mathrm{m} / \mathrm{s})$ distribution inside the drying chamber

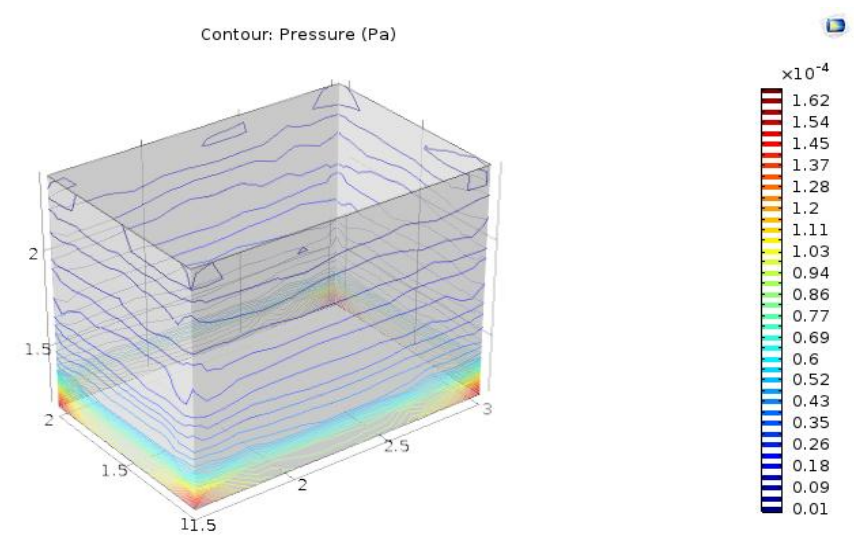

Fig. 7. Air pressure (Pa) distribution inside the drying chamber 
Fig. 7 showed that the mean air pressure inside the drying chamber ranged from $1.5 \times 10^{-4} \mathrm{~Pa}$ at the corners of the bottom of it at the inlet point to $0.25 \times 10^{-4}$ to $0.6 \times 10^{-4} \mathrm{~Pa}$ at the rest and the upper side of it.

\section{Moisture content of strawberry during solar drying:}

Figure 8 shows the strawberry (whole and half fruits) during the solar drying process inside the drying chamber.

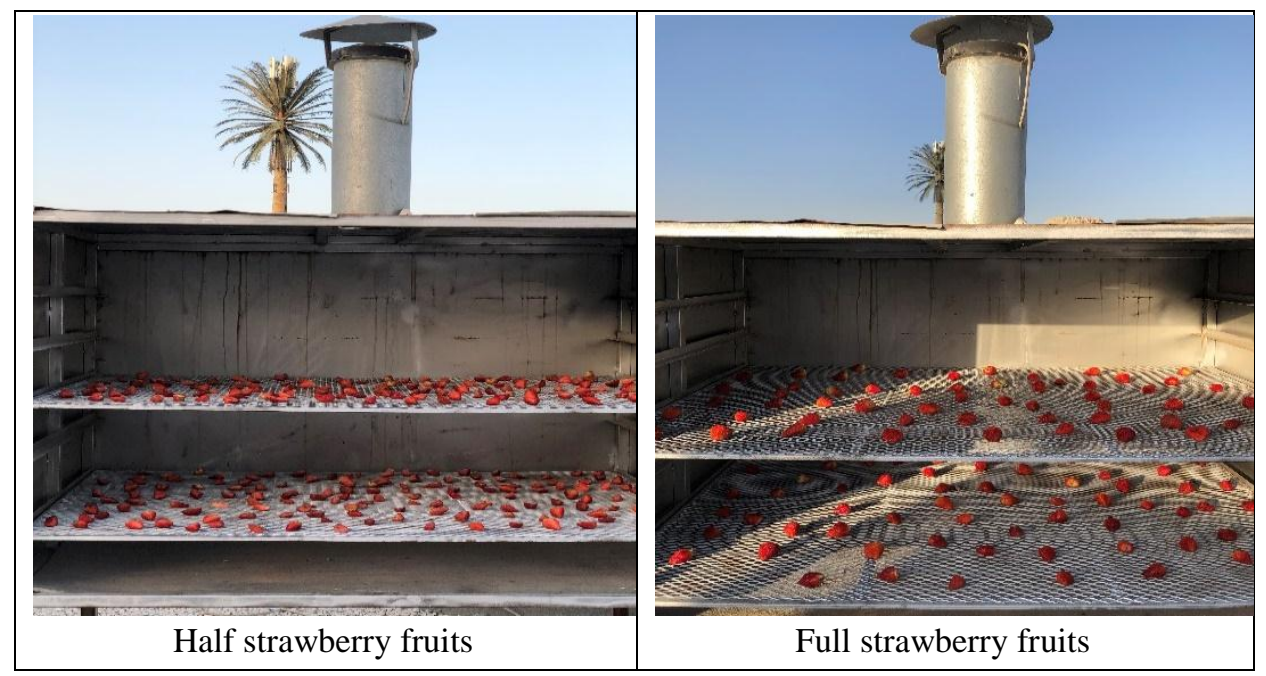

Fig. 8. Half and whole strawberry fruits inside the drying chamber

Figure 9 shows that there is a slight difference in moisture content of strawberry between whole and half fruits at the same measured point during solar drying process using this solar dryer and the sun drying. The mean of fresh fruits moisture content was $85.4 \%$ (w.b.) and the mean of final dried strawberry was around $5.2 \%$ (w.b.). This implies that the moisture content for strawberry during solar drying for half fruits (16 hours) remained higher than moisture content whole fruits (26 hours) most likely because of the product temperature during the process. The similar trend was found at the sun drying, however it dried in longer time for half fruits (23 hours) and whole fruits (40 hours), respectively (Fig. 9).

\section{Moisture diffusivity of strawberry during solar drying:}

There is a difference between the values of $D_{\text {eff }}$ obtained for strawberry based on the new model for solar drying and the Fick's second law of diffusion. This difference is possibly because Fick's second law of diffusion is for long drying times. Therefore, it could consider the new 
model to determine $D_{\text {eff }}$ for solar dying is more accurate from Fick's second law of diffusion.

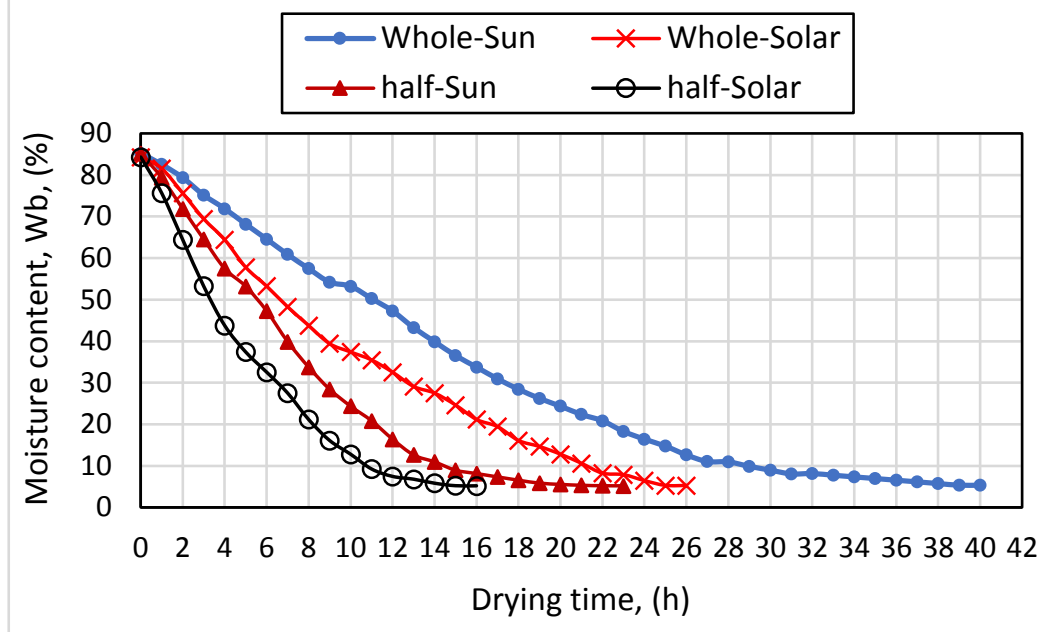

Fig. 9 - Moisture content versus drying time for half and whole strawberry fruits by solar dryer and sun drying

By using Fick's law (equation (7)), but with simplified equation (10) for different portions of the plastic conveyor within the heating zone, it was possible to develop the relationship between moisture diffusivity for strawberry versus drying time for whole and half fruits.

The values of $D_{\text {eff }}$ ranged from $7.2 \times 10^{-9}$ to $9.5 \times 10^{-9} \mathrm{~m}^{2} / \mathrm{s}$, respectively. These values were within the general range $10^{-6}-10^{-13} \mathrm{~m}^{2} / \mathrm{s}$ for drying of several of food materials while the majority (92\%) falls within $10^{-12}$ and $10^{-8} \mathrm{~m}^{2} / \mathrm{s}$, (Zogzas et al. 1996). However, these results were agreed also with (Doymaz. 2008) who found the diffusion coefficient for drying kinetics of strawberry in a laboratory dryer varied from $4.95 \times 10^{-10} \mathrm{~m}^{2} / \mathrm{s}$ to $1.42 \times 10^{-9} \mathrm{~m}^{2} / \mathrm{s}$. In addition, the values of $D_{\text {eff }}$ for strawberry leather ranged from $2.40 \times 10^{-9}$ to $12.10 \times 10^{-9} \mathrm{~m}^{2} / \mathrm{s}$ depending on drying conditions, (Lee and Hsieh, 2008).

\section{Modeling drying process and selection of best fitting model:}

The coefficients of the selected 10 drying models for whole and half fruits of strawberry used in the solar drying system are presented in Table 4.

The results show that the Logarithmic model had the highest values of $R^{2}$ and the lowest values of $\chi^{2}$, RMSE and EF. 
Table 4. Statistical analysis for the models for drying strawberry

\begin{tabular}{|c|c|c|c|c|c|}
\hline Mode name & Model constants & $\mathbf{R}^{2}$ & $\chi^{2}$ & RMSE & EF \\
\hline Newton & $\mathrm{k}=0.027$ & 0.9994 & $9.51 \mathrm{E}-05$ & 0.00912 & 0.9996 \\
\hline Henderson & $\mathrm{a}=0.997, \mathrm{k}=0.027$ & 0.9994 & $1.11 \mathrm{E}-04$ & 0.00912 & 0.9996 \\
\hline Page & $\mathrm{k}=0.041, \mathrm{n}=0.902$ & 0.9995 & $8.99 \mathrm{E}-05$ & 0.00821 & 0.9997 \\
\hline Modified Page & $\mathrm{k}=0.028, \mathrm{n}=0.902$ & 0.9995 & $8.99 \mathrm{E}-05$ & 0.00821 & 0.9997 \\
\hline Logarithmic & $\begin{array}{l}\mathrm{a}=0.981, \mathrm{k}=0.028 \\
\mathrm{c}=0.015\end{array}$ & 0.9997 & $7.45 \mathrm{E}-05$ & 0.00683 & 0.9998 \\
\hline *Two-term & $\begin{array}{l}\mathrm{a}=0.943, \mathrm{k}_{1}=0.031 \\
\mathrm{~b}=0.058, \mathrm{k}_{2}=0.007\end{array}$ & 0.9998 & $7.37 \mathrm{E}-05$ & 0.00609 & 0.9998 \\
\hline $\begin{array}{l}\text { Two-term } \\
\text { exponential }\end{array}$ & $\mathrm{a}=0.517, \mathrm{k}=0.041$ & 0.9996 & $7.56 \mathrm{E}-05$ & 0.00753 & 0.9997 \\
\hline Midilli et al. & $\begin{array}{l}\mathrm{a}=1, \mathrm{~b}=0.00003 \\
\mathrm{n}=0.948, \mathrm{k}=0.035\end{array}$ & 0.9996 & $1.09 \mathrm{E}-04$ & 0.00739 & 0.9997 \\
\hline \begin{tabular}{l|} 
Diffusion \\
approximation
\end{tabular} & $\begin{array}{l}a=0.942, b=0.241 \\
k=0.032\end{array}$ & 0.9997 & $7.48 \mathrm{E}-05$ & 0.00684 & 0.9998 \\
\hline Verma et al. & $\begin{array}{l}\mathrm{a}=0.942, \mathrm{k}=0.030 \\
\mathrm{~g}=0.008\end{array}$ & 0.9997 & $7.48 \mathrm{E}-05$ & 0.00684 & 0.99978 \\
\hline
\end{tabular}

* This model gives the closest result to the experimental results

Table 2 showed that generally $R^{2}$ varied between 0.9994 and $0.9998, \chi^{2}$ varied between $2.6 \times 10^{-4}$ and $7.39 \times 10^{-5}$, RMSE varied between 0.00608 and 0.01245, and EF values varied between 0.9995 and 0.9998, respectively. The highest $R^{2}$ and EF values were obtained by using the two term model, the approximation of the diffusion model and the Verma et al. model. Those three models may be selected to represent the thin layer drying behavior of strawberry. However, the results have shown that the $\chi^{2}$ and RMSE values of the two-term model was slightly lower than the values obtained by approximation of the diffusion model and the Verma et al. model. Therefore, the two-term model was selected to represent the thin layer drying behavior of strawberry according to the highest values of $R^{2}$ (0.9998) and EF (0.9998), and lowest values of $\chi^{2}\left(7.37 \times 10^{-5}\right)$ and RMSE (0.00609), respectively. This result was agreed with the result for foamed strawberry pulp (Lee \& Hsieh, 2008). The two-term model (Eq. (18)) is the appropriate model to describe thin layer drying curves of strawberry.

$$
M R=a \exp \left(-k_{1} t\right)+b \exp \left(-k_{2} t\right)
$$

The performance of the two-term model of strawberry fruits for the solar dryer are illustrated in Fig. 10. The predicted data generally banded around 
the straight line which showed the suitability of two-term model for describing drying behavior of strawberry.

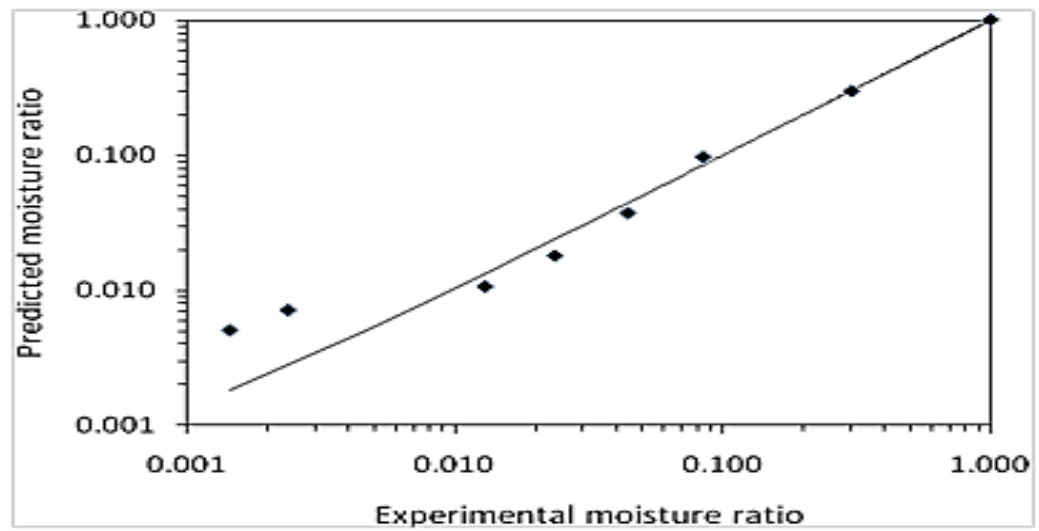

Fig. 10 - Experimental moisture ratio versus predicted moisture ratio by two term model for for strawberry fruits by solar dryer.

\section{Evaluation of color parameters for strawberry:}

The individual color parameters of fresh strawberry fruits were taken as a reference in order to evaluate the extent of color change. These values and the statistical results of the color measurements of strawberry dried for whole and half fruits in table 5.

Table 5. color parameters of fresh and dried strawberry (whole and half fruits)

\begin{tabular}{|c|c|c|c|}
\hline Color parameters & Fresh plants & Whole fruits & half fruits \\
\hline $\mathrm{L}^{*}$ & 30.76 & 20.38 & 20.10 \\
\hline $\mathrm{a}^{*}$ & 22.23 & 18.17 & 18.74 \\
\hline $\mathrm{b}^{*}$ & 12.72 & 9.85 & 9.83 \\
\hline
\end{tabular}

The results showed non-significant effect on the color parameters of the fruits as expressed by $\mathrm{L}^{*}, \mathrm{a}^{*}$ and $\mathrm{b}^{*}$ values of dried strawberry for whole and half fruits.

\section{CONCLUSION}

COMSOL Multiphysics computer program was used the dimensions of the solar collector and the drying chamber, the measured inlet and outlet of the air characteristics to simulate the distribution of the air temperature, air velocity and pressure inside the solar collector and the drying chamber. It found that the air characteristics inside both of these parts were almost equivalent and it was in small scale difference. 
This soar drying system could provide further improvement for the performance of the pervious same type of solar dryers. It has the following advantages such as: movable to can be directed according to sun's angle, besides it could connect to photovoltaic modules and batteries to can store energy and operate dc fan and dc water pump in the drying system. It is found suitable for drying agricultural products as strawberry.

The drying of strawberry in a solar dryer was investigated and the experimental data modeled by fitting 10 thin layer equations by direct least squares procedure. The drying characteristics of strawberry for solar drying conditions were studied and model parameters were compared using 4 statistical parameters. A two-term model was found to be the best model for describing the drying kinetics of the strawberry in a solar drying system. The moisture diffusivity for strawberry fruits was ranged from $7.2 \times 10^{-9}$ to $9.5 \times 10^{-9} \mathrm{~m}^{2} / \mathrm{s}$.

\section{RECOMMANDITIONS}

This solar drying system can be used to determine the moisture diffusivity of other vegetables or fruits. Reducing the drying time of strawberry could be obtained by the current solar drying system compared to sun drying.

\section{REFERENCES}

Afzal, T. M. and Abe, T. (2000). Simulation of moisture changes in barley during far-infrared radiation drying. Comput. Electron. Agric., 26(2): 137-145.

Akpinar, E., Midilli, A. and Bicer, Y. (2003). Single layer drying behavior of potato slices in a convective cyclone and mathematical modeling. Energy Conversion Management, 44, 1689-1705.

Amer, B. M. A., Hossain, M. A. and Gottschalk, K. (2010). Design and performance evaluation of a new hybrid dryer for banana. Energy Convers. Manag., 2010, 51(4): 813-820.

Arinze, E.A., G.J. Schoenau, and S. Sokhansanj, (1999) Design and experimental evaluation of a solar dryer for commercial high-quality hay production. Renew. Energy16, 639-642.

Cengel, Y. A. (2003). Heat Transfer: A Practical Approach, $2^{\text {nd }}$ ed., McGraw-Hill. 
Chakraverty, A. and Singh, R. P. (1988). Post Harvest Technology of Cereals, Pulses and Oilseeds, Oxford and IBH Publishing Co. Pvt. Ltd, New Delhi, India.

Chhinnan, M. S. (1984). Evaluation of selected mathematical models for describing thin-layer drying of in-shell pecans. Transactions of the ASAE, 27, 610-615.

Crank, J. (1975). The Mathematics of Diffusion; Oxford University Press: Oxford.

Diamante, L. M. and Munro, P. A. (1991). Mathematical modeling of hot air drying of sweet potato slices. International Journal of Food Science and Technology, 26, 99-109.

Doymaz, I. (2008). Convective drying kinetics of strawberry. Chemical Engineering and Processing, 47(5): 914-919.

El-Beltagy A., G. R. Gamea, A. H. Amer Essa. (2005). Solar drying characteristics of strawberry. J. of Food Eng., 78 (2007) 456-464.

FAOSTAT. (2018). Strawberry world production. Retrieved from http://www.fao.org/faostat/en/\# data/QC.

Hepbasli, A. (2008). A key review on exergetic analysis and assessment of renewable energy resources for a sustainable future, Renewable and Sustainable Energy Reviews, Vol. 12, (3).

Henderson, S. M. (1974). Progress in developing the thin layer drying equation. Transactions of the ASAE, 17, 1167-1172.

Karathanos, V. J. and Belessiotis, V. G. (1999). Application of a thinlayer equation to drying data of fresh and semi-dried fruits. Journal of Agricultural Engineering Research, 74, 355-361.

Kassem, A. S. (1998). Comparative studies on thin layer drying models for wheat. In Proceedings of the 13th international congress on agricultural engineering, Morocco.

Lee, G. and Hsieh, F. (2008). Thin-layer drying kinetics of strawberry fruit leather. Transactions of the ASABE, 51(5): 1699-1705

Madamba, P. S. (2003). Thin layer drying models for osmotically predried young coconut. Drying Technology, 21, 1759-1780. 
Maskan, A., Kaya S. and Maskan, M. (2002). Hot air and sun drying of grape leather (pestil). Journal of Food Engineering, 54(1): 81-88.

Midilli A., Kucuk H. and Yapar Z. (2002). A new model for single layer drying. Drying Technology, 20: 1503-1513.

Rahman, M. S. and Lamb, J. (1991). Air drying behavior of fresh and osmotically dehydrated pineapple. Journal of Food Process Engineering, 14 (3), 163-171.

Rahman, M. S., Perera, C. O. and Thebaud, C. (1998). Desorption isotherm and heat pump drying kinetics of peas. Food Research International, 30 (7), 485-491.

Ratti, C. and Kudra, T. (2006). Drying of Foamed Biological Materials: Opportunities and Challenges. Drying Technology, 24: 9, 1101 1108.

Sarsavadia, P. N., Sawhney, R. L., Pangavhane, D. R. and Singh, S. P. (1999). Drying behavior of brined onion slices. Journal of Food Engineering, 40, 219-226.

Shalaby, S.M., and M.A. Bek, (2014). Experimental investigation of a novel indirect solar dryer implementing PCM as energy storage medium, Energy Convers. Manag. 83: 1-8.

Sharaf-Eldeen, Y. I., Blaisdell, J. L. and Hamdy, M. Y. (1980). A model for ear corn drying. Transaction of the ASAE, 23, 1261-1271.

Sodha, M. S.; Bansal, N. K.; Kumar, A.; Bansal, P. K. and Malik, M. A. S. (1987). Solar Crop Drying. CRC Press, Inc. Boca Raton, Florida.

Togrul, I. T. and Pehlivan, D. (2003). Modelling of drying kinetics of single apricot. Journal of Food Engineering, 58: 23-32.

Vengaiah, P. C. and Pandey, J. P. (2007). Dehydration kinetics of sweetpepper (Capsicum anuum L.). Journal of Food Engineering, 81: 282-286.

Verma, L. R., Bucklin, R. A., Endan, J. B. and Wratten, F. T. (1985). Effects of drying air parameters on rice drying models. Transaction of the ASAE, 28, 296-301. 
Vlachos, N.A., Karapantsios, T.D., Balouktsis, A.I., and Chassapis, D. (2002). Design and testing of a new solar tray dryer. Dry. Technol. 20: 1243-1271.

White, G. M., Ross, I. J. and Ponelert, R. (1981). Fully exposed drying of popcorn. Transactions of the ASAE, 24, 466-468.

Yam, K. L., \& Papadakis, S. (2004). A simple digital imaging method for measuring and analyzing color of food surfaces. Journal of Food Engineering, 61, 137-142.

Zogzas, N. P., Maroulis, Z. B. and Marinos-Kouris, D. (1996). Moisture Diffusivity Data Compilation in Foodstuffs. Drying Technology, 14: (10), 2225 - 2253.

$$
\text { الملخص العربيى }
$$

محاكاة لخصائص الهواء لنظام التجفيف الهجين المزود بخلية شمسية وحركية تجفيف ثمار الفراولة الهفين

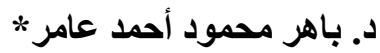

تعتبر الفراولة من أهم المنتجات الزر اعية التي يمكن تجفيفها لتكون موجودة طو ال العام ، ولكنها

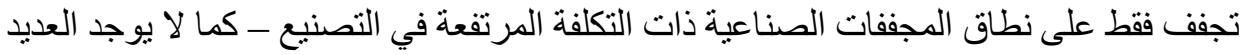
من الأبحاث لتطوير طرق تجفيف ثمار الفراولة واستخدامها على نطاق المجففات الشمسية لتقليل

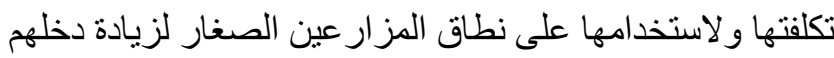

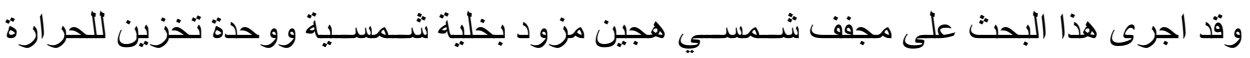
بالماء وذللك لتجفيف ثمار الفراولة الكاملة وأنصافها

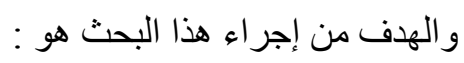

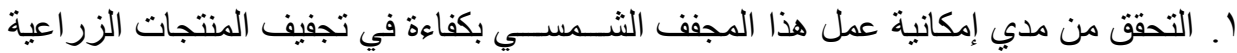

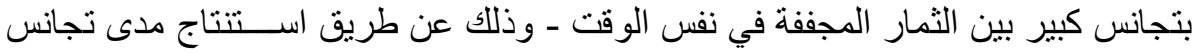

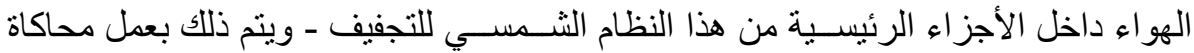

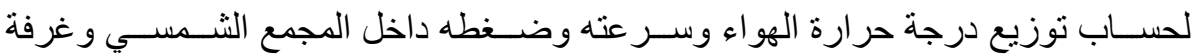

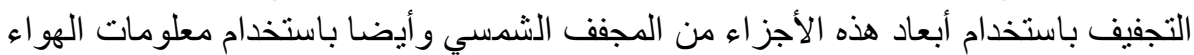

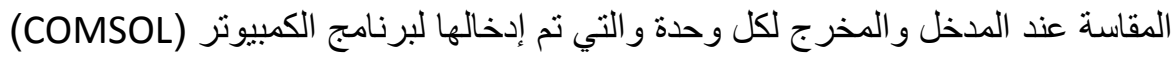

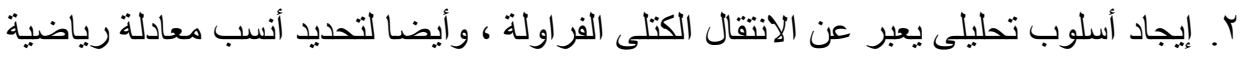

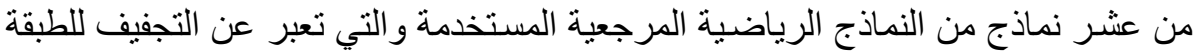
الأحادية (Thin-layer) من ثمار الفراولة ويمكن أن تتوافق مع هذا النوع من المجفقات .

*استاذ الهندسة الزراعية المساعد ـ كلية الزراعة - جامعة القاهرة - والمعار بكلية العلوم الزراعية والأغذية ـ جامعة الملك فيصل بالسعودية المنة 


\section{و قد بينت الار اسةة ما يلي:}

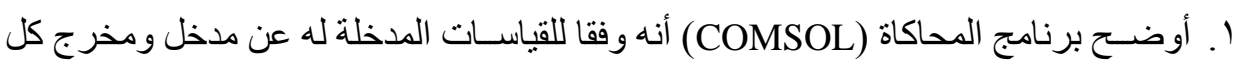

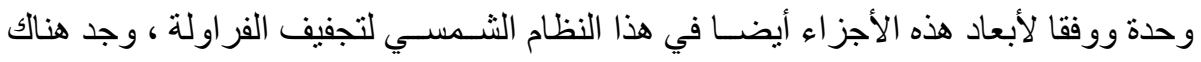

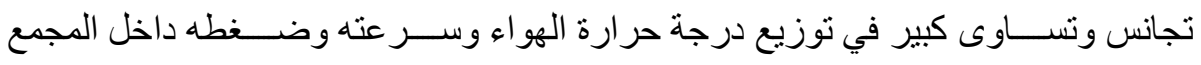

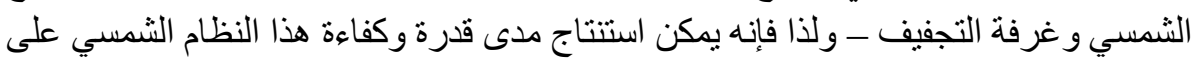
إدكاذية تجفيف العديد من المنتجات الزراعية بتجانس كبير في در جة التجفيف بين الثمار

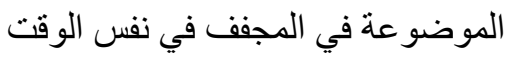

r. النموذج الرياضى باسم " two-term " هو أنسب علاقة رياضية تعبر عن التجفيف للطبقة

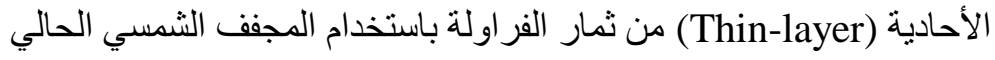

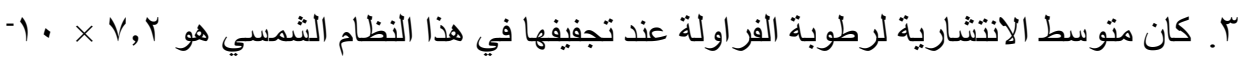

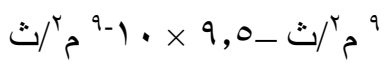

ع. لا يوجد فروق معنوية في اللون بين الثمار المجففة للفراولة سو اء كاملة أو أنصاف.

التوصيات

ا ـ يمكن استخدام المجفف الحالي في تقدير الانتشارية لرطوبة منتجات أخرى.

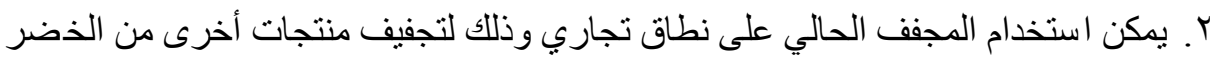
و الفاكهة. كما يمكن تقليل وقت التجفيف بهذا المجفف الشمسي مقارنة بالتجفيف الطبيعي. 